\title{
Revolutions of the Dharma Wheel: Uses of Tibetan Printing in the Eighteenth Century
}

\author{
Benjamin J. Nourse
}

As there are not, to my knowledge, any established periodizations of the history of Tibetan printing, I would like to begin by briefly sketching out some of the critical eras in the development of printing technology for use in Tibetanlanguage publishing. The study of Tibetan printing history has, for good reasons, focused on developments in central and western Tibet (dBus gTsang and mNga' ris) during the fifteenth and sixteenth centuries. In this key period, printing became an established craft on the Tibetan plateau. But this was not the only important era of Tibetan printing. The history of Tibetan printing can, in very general terms, be divided into four main periods: (1) Tibetanlanguage publishing under the sponsorship of non-Tibetan central Asians such as the Tanguts and the Mongols (12th-14th centuries); (2) the rise of central and western Tibetan printing (15th-16th centuries); (3) the continued spread of printing, including into eastern Tibet and Mongolia, and the publication of canons (18th-19th centuries); and (4) the adoption of non-woodblock printing technologies (2oth century). We could add to these key periods of intensive growth in Tibetan printing several other significant milestones, such as the simultaneous publication and suppression of literature by the dGa' ldan pho brang government beginning in the latter half of seventeenth century or the first xylograph editions of the bKa' 'gyur - produced by the Ming dynasty (15th c.) and the kingdom of 'Jang Sa tham (16th c.), both non-Tibetan polities.

* Research for this paper was carried out through the support of a Fulbright-Hays Fellowship from the us Department of Education, a Florence Tan Moeson Fellowship from the Asian Division of the Us Library of Congress, and a grant-in-aid from the Friends of the University of Wisconsin-Madison Libraries. I would also like to thank the staff of the sDe dge Printing House for their assistance during my visit and Chris Gist of the University of Virginia Library for his help orienting me in the use of ArcGIS software for map making.

(C) BENJAMIN J. NOURSE, 2016 | DOI 10.1163/9789004316256_020

This is an open access chapter distributed under the terms of the Creative Commons Attribution-

Noncommercial 3.0 Unported (CC-BY-NC 3.0) License. 
This general outline of Tibetan printing history is offered as an initial attempt at periodization and of course may require revision as more evidence comes to light. Regardless, the development of such frameworks can help us think through the larger trajectory of Tibetan printing and place individual printing projects or eras into a broader context. In this paper, I will be concerned mainly with developments in the third period suggested above - the spread of printing especially during the eighteenth century - while at the same time noting some continuities and differences between the earlier fifteenth and sixteenth-century publishing environment and that of the eighteenthcentury. In order to do so, I will first look at several examples of well-known works or collections that were the subject of early Tibetan printing projects and trace these works' subsequent printing histories.

The political landscape of the eighteenth century was one in which several polities grew rapidly, consolidated their power, and built their institutional bases. These polities included the Qing dynasty, the dGa' ldan pho brang government in central Tibet, Bhutan under the Zhabs drung and their regents, and the kingdoms of Co ne and sDe dge in eastern Tibet. In addition, the eighteenth century saw the development of a host of mega-monasteries, especially within the dGe lugs pa school. These large monasteries housed thousands of monks and became substantial landowners with significant political clout of their own. Most of these new centres of power, polities and monasteries, became major publishers of woodblock editions of Tibetan texts. In the latter part of the paper, I will explore the development of several of these new printing centres with an eye toward how the texts produced at these centres may have been regarded and used. The amount of texts from eighteenth-century publishers that survive or are recorded in Tibetan sources provide us with an opportunity to speculate about some of the more specific uses of printing and printed books during that century.

We don't know the full extent of printing in fifteenth-century Tibet, but from currently available evidence it seems that in terms of larger projects there was a focus on the collected works (or a selection of works) by the luminaries of particular schools and traditions. An example of this is the printing of works composed by Tsong kha pa Blo bzang grags pa (1357-1419), which began not long after his death (Jackson 1983, 6; Jackson 1989, 5). These were published in dBus, near the centres of the emerging dGe lugs pa school around Lhasa and dGa' ldan monastery. They were produced with the support of Grags pa rgyal 
mtshan (1374-1432), the ruler of the Phag mo gru pa government who was an important patron of Tsong kha pa and the early dGe lugs pa school. The publication of Tsong kha pa's works during this early period of woodblock printing in Tibet was probably one factor among many in the success of the dGe lugs pa school. However, it is not until the eighteenth century that we see his collected works published in several editions. They were printed in Beijing as a supplement to the bsTan 'gyur published with Qing imperial support in $1724 .{ }^{1}$ At Co ne, a dGe lugs pa monastery in A mdo, we find the publication of Tsong kha pa's collected works under the direction of Blo bzang bstan pa'i rgyal mtshan (b. 1708), a member of the Co ne royal family and the abbot of the Co ne dgon chen (dKon mchog 'jigs med dbang po 1986, 423.20-424.5, 426.4-6). Other editions of Tsong kha pa's collected works from dGe lugs pa institutions include those from the Zhol par khang, bKra shis lhun po, sKu 'bum, Bla brang, and 'Bras spungs, all of which date from the eighteenth century or later. ${ }^{2}$

Around the same time that Tsong kha pa's works were first being printed, works of the early Sa skya pa masters were being published in gTsang (Jackson 1983,6 ). Toward the middle of the same century an edition (possibly incomplete) of the Sa skya bka' 'bum was published in dBus under the sponsorship of Gong dkar rdo rje gdan pa Kun dga' rnam rgyal (1432-96) (Jackson 1989, 11). We do not currently know of other editions of the Sa skya bka' 'bum that were printed before the collection was published at sDe dge in $1736 .{ }^{3}$ It is not

1 A facsimile reprint of this edition is in The Tibetan Tripitaka (1961, vols. 152-161).

2 The Zhol par khang edition has been reprinted as The Collected Works (gsung 'bum) of the Incomparable Lord Tsong-kha-pa Blo-bzang-grags-pa (New Delhi: Mongolian Lama Gurudeva, 1978-79), твкс: http://tbrc.org/\#!rid=W635. This publication dates the Zhol edition to 1897. The bKra shis lhun po edition has been reprinted as The Collected Works (gsung 'bum) of Rje Tsong-kha-pa Blo-bzang-grags-pa (New Delhi: Ngawang Gelek Demo, 1975-), TвRC: http://tbrc.org/\#!rid=W22109, and more recently as Rje yab sras gsum gyi gsung bum, vols. 1-18 (Dharamsala: Sherig Parkhang, 1998), твRC: http://tbrc.org/\#!rid=W29193. Dung dkar Blo bzang 'phrin las (2004, 140-41) dates the bKra shis lhun po edition to the time of Pan chen Blo bzang ye shes (1663-1737). Digital reproductions of the sKu 'bum and Bla brang editions are avaible on твRс: http://tbrc.org/\#!rid=W22272 and http://tbrc.org/\#!rid=W22273 respectively. твкс dates the sKu 'bum edition to the nineteenth century. The digital reproduction of the Bla brang edition is based on a recent impression made from woodblocks at Bla brang which are probably not the originals. Tsong kha pa's collected works were also published in sDe dge, but not until the early twentieth century under the patronage of A ja rdo rje seng ge; see твкс digital reproduction of the sDe dge edition: http://www.tbrc .org/\#!rid=W22274.

3 Jackson $(1983,16)$ notes that a list of printing blocks in central Tibet compiled in the midtwentieth century contains a listing of an edition of the Sa skya bka" 'bum listed under "dPal di rdzong." Jackson speculates that this could be the old Gong dkar ba edition, but it could also be some other yet unidentified edition of this collection. 
surprising that the sDe dge court sponsored this project. Printing in sDe dge focused on works of the Sa skya pa school and in particular the Ngor pa subsect of the Sa skya pa school with which sDe dge had an especially close relationship. In fact, the primary early instigator of printing at sDe dge was Sangs rgyas phun tshogs (1649-1705), the twenty-fifth Great Abbot (mkhan chen) of Ngor E wam chos ldan monastery.

Sangs rgyas phun tshogs was invited to sDe dge by its ruler in 1699. He died in 1705 , but spent the last years of his life in and around sDe dge. During that time he encouraged the royal court of sDe dge to print scriptures (Mu po 2002, ${ }_{136-141)} \cdot{ }^{4}$ We find him mentioned in the nineteenth-century historical work the Royal Genealogy of sDe dge (sDe dge'i rgyal rabs) by Tshe dbang rdo rje rig 'dzin (b. 1786) as the key figure in the publication of one of the first, perhaps the very first, printed work produced in sDe dge - a bilingual xylographic edition of the Eight-Thousand Verse Perfection of Wisdom ('Phags pa shes rab kyi pha rol tu phyin pa brgyad stong pa) with illustrations of the twelve acts of the Buddha (Tshe dbang rdo rje rig 'dzin 1994, 19b.1-3). The patron of this and other early publications was Sangs rgyas bstan pa, the third abbot of the sDe dge dgon chen and the king of sDe dge for several decades in the latter half of the seventeenth century (Kolmas 1968, 34; Ronis 2009, 65).

A series of abbatial throne holders from Ngor e wam chos ldan monastery followed the example of Sangs rgyas phun tshogs and made extended journeys to sDe dge periodically throughout the eighteenth century (Mu po 2002, 157-58 and 169; Jackson 1996, 311-314). The steady stream of lamas from Ngor were no doubt aware of the favorable conditions in sDe dge under the patronage of the royal court, including support for printing projects. Many of the printing activities at sDe dge were said to be undertaken at the request of these hierarchs of Ngor and often reflect their sectarian interests. For example, two early publications at sDe dge carried out in 1705 were the famous Excellent Sayings of Sa skya [Pandita] (Sa skya legs bshad) and the Religious History of Ngor (Ngor chos 'byung). ${ }^{5}$ The sDe dge printing house continued to publish the collected works

4 Note however that $\mathrm{Mu}$ po $(2002,139)$ identifies the sDe dge ruler who made the invitation as "sde dge sa skyong bla ma tshe dbang rdo rje." This biography seems to be mistaking the nineteenth-century sDe dge ruler and writer of the sDe dge'i rgyal rabs, Tshe dbang rdo rje rig 'dzin, for a late seventeenth-century ruler.

5 These two works are still held by the sDe dge Printing House. The printer's colophon to the Sa skya legs bshad (Kun dga' rgyal mtshan 1705, 26b.3-4), which I transcribed from the sDe dge blocks, reads: lugs gnyis kyi blang dor gsal bar ston pa legs par bshad pa rin po che'i gter zhes bya ba'i bstan bcos 'di nyid srid mthar dar zhing rgyas ba'i ched du sa skyong shing bya lor sde dge lhun grun steng du sde dge bla ma sangs rgyas bstan pas chos sbyin mi zad pa'i rgyun spel ba 'dis bstan pa dang sems can la phan pa'i rgyur gyur cig//. On this publication, see also Zhaxia $(2008,112)$. The printer's colophon to the Ngor chos 'byung may be found in the Indian 
and biographies of other Sa skya and Ngor masters throughout the course of the eighteenth century.

Beyond the examples of Tsong kha pa's collected works or the Sa skya bka' 'bum and other publications from sDe dge, a cursory overview of the publications issuing from eighteenth-century printing centres would seem to indicate that the printing of many Tibetan texts was undertaken along sectarian lines. Printing at the Qing court, in Lhasa, and in A mdo, often favored the dGe lugs pa school with collections such as the collected works of Tsong kha pa and his immediate disciples. In Bhutan, works related to the 'Brug pa bKa' brgyud pa school were sponsored, such as the collected works of Padma dkar po. Further investigation into the publication history of smaller collections or individual texts may be able to demonstrate whether Tibetan publishing was indeed as sectarian as the few examples I have discussed here would indicate.

3

Classics

While printing often focused on texts of sectarian or local importance, some pieces of Tibetan literature were able to transcend regional and sectarian affiliations. Prime examples of this type of literature include the Life and Songs of Milarepa (Mi la'i rNam thar and mGur 'bum), the Collected Pronouncements of the Mani (Ma ni bka' 'bum), and the Four Tantras (rGyud bzhi) - titles that Franz-Karl Ehrhard (2000a, 14) has described even in the context of fifteenthcentury printing as "Buddhist classics." But while these works were first printed in the fifteenth and sixteenth centuries, evidence for their appeal beyond certain lineages and localities is generally not evident in their publication history until the eighteenth century.

For example, among the eighteen woodblock editions of gTsang smyon $\mathrm{He}$ ru ka's Life and Songs of Milarepa (Map 19.1) that I have so far been able to identify, we find that the first edition was printed shortly after the composition of these works the late fifteenth century. ${ }^{6}$ This was followed by a quick succession of four other editions through the mid-sixteenth century. Then the rate of production slows considerable for the next century and a half (only one new edition made). In the eighteenth century, however, at least five new editions were carved, and there were likely more. And, whereas the earlier prints

reprint of the sDe dge edition (dKon mchog lhun grub and Sangs rgyas phun tshogs 1973, $457.2-458.2$ ).

6 Sources relating to editions of the Mi la'i rNam thar and $m$ Gur 'bum are given in note 27 . 
had all been made in relatively close geographic proximity to one another and largely by bKa' brgyud pa figures in the lineage of the author, gTsang smyon He ru ka, the eighteenth-century editions cover a large geographic extent (Bhutan, Beijing, sDe dge in Khams, and Co ne and g.Yer gshong in A mdo) and were published by figures and institutions representing a range of Tibetan sectarian allegiances.

We find a similar trend for the printings of the Collected Pronouncements of the Mani (Map 19.2). ${ }^{7}$ Of the editions that I have found mentioned in Tibetan or secondary sources, there were two early xylograph editions - one produced in the late fifteenth century and one in the early sixteenth century. They both were made in rDzong dkar in Mang yul Gung thang. After these, we do not see any more new editions until the eighteenth century when at least four editions were published within a few decades of each other. Editions of the Collected Pronouncements of the Mani were produced in Bhutan, Co ne, sDe dge, and Beijing, all sites of emerging political powers at the time.

In the publications of the Four Tantras, we find a different pattern from the above two examples (Map 19.3). ${ }^{8}$ While we again see an early edition from Mang yul Gung thang, this fundamental collection of the Tibetan medical tradition went through at least five editions in the seventeenth century, two of which were products of the newly formed dGa' ldan pho brang government in Lhasa. This seems to go against the general trend of finding the bulk of editions before and after the seventeenth century. In fact, apart from the publishing activities of the Jo nang pa monastery of rTag brtan phun tshogs gling in the first half of the seventeenth century, there is a general lack of evidence of concerted efforts at woodblock printing in that century by institutions other than the dGa' ldan pho brang government, which became the dominant central Tibetan publisher in the late seventeenth century. This gap in evidence may be related to the activities of the same government to limit or control the use of printing and the dissemination of texts by others, the foremost example of which is the conversion of rTag brtan phun tshogs gling to the dGe lugs pa school, after which the printing of many texts from that monastery's sizable printing house was restricted (on this and other printing bans see Smith 2004). The relatively large amount of seventeenth-century editions of the Four Tantras, however, did not curtail further publications of these texts in the

7 Sources relating to editions of the Ma ni bka' 'bum are given in note 28 .

8 Sources relating to editions of the rGyud bzhi are given in note 29 . 
eighteenth century, including editions from sDe dge, Beijing, and sKu 'bum, and likely the dBang 'dus pho brang edition produced in Bhutan as well.

\section{$4 \quad$ An Age of Canons: The Prestige and Merit of Printing}

While the classics we have looked at so far all had a precedent of publication in central or western Tibet in the fifteenth century, there was no Tibetan precedent for eighteenth-century publications of perhaps the greatest of Buddhist classics, the bKa' 'gyur and bsTan 'gyur. While the bKa' 'gyur had been previously printed in China and in the Naxi kingdom of 'Jang Sa tham, the eighteenth century witnessed the production of editions of both the bKa' 'gyur and the bsTan 'gyur in Beijing as well as the Tibetan areas of Co ne, sDe dge, and sNar thang. In no other century were more xylograph editions of canons produced than in the eighteenth century. ${ }^{9}$ This is in sharp contrast to the fifteenth and sixteenth-century printing boom in central Tibet which in comparison saw relatively little printing of canonical literature..$^{10}$

The first Tibetan kingdom to print the bKa' 'gyur was Co ne, in A mdo (in today's Gansu province of China). The fortunes of the Co ne kings rose with the Qing dynasty, which they often aided militarily in the late seventeenth and eighteenth centuries. Around the year 1711, the king of Co ne, dMag zor mgon po (b. 1686), and his brother, Ngag dbang'phrin las rgya mtsho (1688-1738), who was abbot of the Co ne dgon chen, went to Beijing for an audience with the Kangxi emperor. During this trip, Ngag dbang 'phrin las rgya mtsho, the abbot, paid two thousand silver srang in order to bring a print of the Beijing bKa' 'gyur back to Co ne for installation in its new Jo bo lha khang (dKon mchog 'jigs med dbang po 1986, 385.12-14 and 402.1-3). Acquiring the newly completed edition of the bKa" gyur from the palace of the emperor was likely a factor in the decision

Xylograph editions of the bKa' 'gyur and bsTan 'gyur that were not made in the eighteenth century include theYongle bKa' 'gyur (15th c.), the Wanli bKa' 'gyur (17th c.), the 'Jang sa tham bKa' 'gyur (17th c.), the first issue of the Beijing bKa' 'gyur (17th c.), the Rwa rgya bKa' 'gyur (19th c.), the Urga bKa' 'gyur and (unfinished) bsTan 'gyur (2oth c.), the the Wa ra bKa' 'gyur and (unfinished) bsTan 'gyur (2oth c.), and the Lhasa bKa' 'gyur (2oth c.).

There is some evidence of the printing of canonical materials during the early period of printing in Tibet. Leonard van der Kuijp (1993, 289-290; 2004, 10-11) mentions several fifteenth and sixteenth-century publications of canonical texts, such as works by Dignaga and Dharmakīti. Franz-Karl Ehrhard (2000a, 12) mentions the 1439-1441 printing of a gzung 'bum compiled by Bu ston Rin chen drup. However, in general printing seems to have been more frequently utilized for non-canonical works in the fifteenth and sixteenth centuries. 
of the Co ne court to print their own edition of the bKa' 'gyur, a project that began in 1721 and was completed a decade later.

Indeed, later in the eighteenth century when the Co ne queen Rin chen dpal 'dzom printed the bsTan 'gyur at Co ne, competition with other polities is cited as one of her initial motivations, before turning to more pure intentions. We read in the catalogue written for the bsTan 'gyur publication that after some initial feelings of doubt as to the possibility of completing such a grand project, the queen then considered her status and the renown that would result from sponsoring the bsTan 'gyur project:

[The great ruler] thought dejectedly, "How can we accomplish such a difficult endeavor?" Then she thought arrogantly, "I alone can accomplish a task such as this which could not be undertaken by most common people." She thought competitively, "Since in other great countries they have accomplished this excellent course of perfect virtue, I, who am equal to them, also will accomplish it." With fame in mind she thought, "In accomplishing such service to the teachings, all the border people also will praise [me]." (dKon mchog 'jigs med dbang po 1986, 439.18-440.4) ${ }^{11}$

This candid passage suggests that competition was a factor in the eighteenthcentury printings of the bKa' 'gyur and bsTan 'gyur and that prestige was granted to those who could undertake such projects. The act of reproducing and thereby maintaining and protecting the Buddhist teachings was seen as the domain of Buddhist monarchs, and Tibetan rulers who published canons were compared to the great religious protectors of old, as when Si tu pan chen Chos kyi 'byung gnas $(2008,404.11)$ describes the sDe dge king as the second coming (slaryang 'ongs) of Aśoka.

Political leaders, however, were not exclusively motivated by prestige or competition. Canons were also printed because they were powerful sacred objects. Productions of xylograph editions of the bKa' 'gyur and bsTan 'gyur were often carried out for the purposes of merit accumulation, ritual practice, and worship. The catalogues to eighteenth-century xylograph editions of the bKa' 'gyur and bsTan 'gyur describe at length the great merit generated by these

11 In Tibetan: bya dka' ba'i gnas 'di lta bu bdag cag gis ji ltar sgrub nus snyam pa'i zhum pa dang /_skye bo phal mo che sus kyang rtsom par mi nus pa'i gnas 'di lta bu sgrub pa ni bdag nyid 'ba' zhig go snyam pa'i khengs pa dang /_yul gru chen po gzhan dag tu rnam dkar gyi lam bzang po 'di lta bu bsgrubs 'dug pas de dang mtshungs par bdag gis kyang bsgrub par bya'o snyam pa'i 'gran sems dang /_bstan pa'i zhabs tog 'di lta bu sgrub pa la sa mtha'i skye bo rnams gyis kyang bsngags pa 'rjod [read: brjod] par 'gyur ro snyam pa'i grags pa... 
projects, the good results that are likely to result from them, and the protection from evil events and forces gained through the production of bKa' 'gyur and bsTan 'gyur. ${ }^{12}$ To cite just one example, in his catalogue to the sDe dge bKa' 'gyur, Si tu pan chen ends an analysis of several quotations from Buddhist scriptures that describe the merit of copying Buddhist texts by extending the discussion to the merit resulting specifically from printing:

In summary, if each time one writes out a sūtra there are these kinds of benefits, then in tens of thousands of aeons one could not even partially describe the heap of merit resulting from printing an edition consisting of many volumes of sūtra and tantra for the purpose of distributing inexhaustible gifts of Dharma. (Chos kyi 'byung gnas 2008, 514.20-515.2) $)^{13}$

The results of accruing such great stores of merit were said to include peace and prosperity for the kingdom in which the production took place, as well as the continuation of the royal family as rulers and the maintenance of their wealth for generations (see, for example, Chos kyi 'byung gnas 2008, 509.17511.6; and dKon mchog 'jigs med dbang po 1986, 455.1-456.12).

Merit could also be earned through ritual recitations of the canonical collections. Eighteenth-century bKa' 'gyur and bsTan 'gyur catalogues contain several references to rulers ordering such recitations to be performed by monasteries in their domain (for example, Tshul khrims rin chen 1985, 435.12-15; dKon mchog 'jigs med dbang po 1986, 385.10, 397.10-11, 408.16, and 410.19). We might speculate that one use of the printed editions of the bKa' 'gyur and bsTan 'gyur might have been for distribution to regional monasteries, allowing a ruler to greatly amplify ritual readings of these collections.

12 Claims about the accumulation of merit and other results of canonical publications are mostly found in the sections of bKa' 'gyur and bsTan 'gyur catalogues having to do with the benefits (phan yon) to be gained through printing the bKa' 'gyur or bsTan 'gyur (see Chos kyi 'byung gnas 2008, 511-520; Tshul khrims rin chen 1985, 864-875; and dKon mchog 'jigs med dbang po 1986, 456-467).

13 In Tibetan: mdor na mdo sde re re 'dri ba la'ang de lta bu'i phan yon yod na/_mdo rgyud kyi glegs bam mang po'i phyi mo mi zad pa'i chos sbyin spel ba'i phyir par du bsgrubs pa'i bsod nams kyi phung po la ni phyogs tsam zhig kyang bskal pa bye pa phrag mang por brjod pas mtha'gtugs par nus pa mayin no/. 


\section{$5 \quad$ Ritual Liturgies in sDe dge and Beijing}

Merit could also be accrued through the performance or sponsorship of smaller, regularly performed rituals. Whether or not printing added to the amount of ritual recitations of the bKa' 'gyur and bsTan 'gyur, printing was used to produce material for the regular ritual activities of monasteries in the eighteenth century, particularly in the publications of collections of liturgical materials.

At sDe dge, the Ngor abbots who had been responsible for encouraging the court to take up printing also worked to establish new codes of conduct and reinvigorate the monastic ritual calendar. Zhu chen Tshul khrims rin chen in his catalogue to the sDe dge bsTan 'gyur tells us that Ngor abbots like Sangs rgyas phun tshogs and bKra shis lhun grub wrote new monastic customaries (bca'yig) and instituted new annual ceremonies and daily ritual schedules for monasteries throughout the sDe dge kingdom (Tshul khrims rin chen 1985, 433.3-16). At the same time, the sDe dge court financed a large number of these rituals at monasteries within their domain (Tshul khrims rin chen 1985, 445.15-446.1). Zhu chen later in his catalogue mentions the printing of liturgical (chos spyod) materials needed for rituals and recitation. This comes in a roughly chronological listing of several early sDe dge publications. In between Zhu chen's recording of the Sa skya bka' 'bum and the bsTan 'gyur publications, he writes:

Furthermore, around eleven volumes were published and given as gifts of Dharma which included the necessary materials for those liturgies chiefly recited in the Ngor tradition, such as means of accomplishment, maṇdala rituals, offering [rites], and ritual cake [rites], and also the Four Medical Tantras, the Supplement to the Oral Instruction Tantra, and so forth. (Tshul khrims rin chen 1985, 448.18-21) ${ }^{14}$

The liturgical texts mentioned here could have been used in the regular ritual activity of Lhun grub steng and other monasteries in the sDe dge kingdom, particularly if in fact the religious centres of the region were increasingly adopting the same schedule of ritual activities.

14 In Tibetan: gzhan yang ngor lugs gtso bor bton pa'i chos spyod kyi rigs dang /_sgrub thabs dang /_dkyil'khor gyi cho ga dang /_mchod pa dang /_gtor ma la sogs pa nye bar mkho ba'i rigs su gtogs pa dang /_gso ba rig pa'i rgyud bzhi dang /_man ngag rgyud kyi lhan thabs sogs/_bsdoms pa glegs bam bcu gcig tsam par du bsgrubs te chos kyi sbyin pa btang ngo /. 
Several collections of liturgical materials (chos spyod rab gsal) were also published in eighteenth-century Beijing. ${ }^{15}$ Most of these are one-volume collections composed of multiple short prayers and ritual liturgies that would be used in the daily assemblies of a monastery. For example, a collection published in 1731 by the imperial monastery dGa' ldan chos 'khor gling contains thirty short individual texts ranging from prayers of refuge and the cultivation of bodhicitta (skyabs 'gro sems bskyed) to confessional rites (ltung bshags) and ritual cake offerings (gtor 'bul). ${ }^{16}$ Monastic leaders were likely making a practical use of printing in the production of these woodblock editions of frequently used ritual texts.

sDe dge, the Literary Arts, and the Training of Scribes

Another practical application of printed texts in the eighteenth century may have been their use as study materials. Some early sDe dge publications reflect an interest in the literary arts, and these texts may have been in part printed as aids to the staffs at work on the sDe dge printing house's many publishing projects.

The earliest datable sDe dge publication that I have found is a grammar treatise published by Sangs rgyas bstan pa at Lhun grub steng in the wood monkey (shing sprel) year, 1704. This work is a short ( 25 folios) commentary by Chos skyong bzang po (1441-1527) on Thon mi Sam+b+ho Ta's two root texts on Tibetan grammar and spelling. ${ }^{17}$ Sangs rgyas bstan pa's successor to the sDe

15 The University of Wisconsin-Madison Library's Special Collections Department holds prints of several of these collections and Taube $\left(1966,1145^{-1149}\right)$ has catalogued a number of them that are held in German libraries.

16 This is in the Lessing Collection of University of Wisconsin-Madison Libraries' Special Collections Department, nos. 362-88 (see Zwilling 1984, entries 31, 339, 325, 38, 292, 155, 249, 198, 237, 253, 369, 23, 110, 107, 141, 429, 101, 345, 172, 215, 481, 471, 475, 529, 146, 450, 137, and 2). The colophon at the end of the catalogue to this liturgical collection (Lessing no. 388, 3a.1-4) reads: ta'i ching yung ceng rgyal po lo dgu zla ba brgyad pa la yar tshes la/_/cha han bla ma lha kha ba [= khang] dga' ldan chos 'khor gling du legs par bsgrubs//_//yige pa ni dge slong dge legs 'byung nas pris [= bris] pa'o//_//dge bas 'gro rnams sangs rgyas thob parshog/.

17 The blocks for this text, titled 'Gos lo tsā ba d+harma pā las mdzad pa'i bod kyi brda'i bye brag legs par bshad pa sum cu pa dang rtags kyi 'jug pa'i rtsa 'grel, are still held by the sDe dge Printing House. Zhaxia $(2008,112)$, also discusses this text as one of the earliest publications at sDe dge, though only giving a Chinese gloss of the title: Zangwen wenfa [Tibetan Grammar]. 
dge throne, bSod nams phun tshogs, is also credited in colophons with the printing of several short texts. Two of these are also works on grammar and spelling: the Lamp of Speech (Ngag gi sgron ma) by dPal khang Lo tsā ba Ngag dbang chos kyi rgya mtsho (15th/16th c.) and the Clove Pavilion Dictionary (Dag yig li shi'i gur khang) by sMon grub Lo tsā ba Rin chen bkra shis (b. 15th c.). ${ }^{18}$ In these early sDe dge publications we see efforts made to print works on grammar and language arts. One possible reason for this interest could be the use of these and similar texts as practical reference works for a kingdom looking to train literate scribes, likely for the purpose of both writing out scriptures as well as administering the growing domain of the sDe dge kingdom. The printer's colophon to Chos skyong bzang po's text in fact provides a practical purpose for printing the text. It states that the publication was made "having found this root text and commentary to be indispensable to the fulfillment of reading and writing" (Chos skyong bzang po 1704, 25a.1-2).19

18 The blocks for these works are still held by the sDe dge printing house. The printer's colophon for the Ngag gi sgron ma (Ngag dbang chos kyi rgya mtsho, n.d., 21a.4-7) reads: om s+ba s+ti/_brjod bya rang bzhin gyis grub rtsa yi gre'i/_/dbyi bas su gnas pas brjod_dpal khang pa chos mdzad lo tsā bar grags/_byed ngag grub pa/_/gangs can mrda' yi lam du 'dren byed pa'i/_/gtsug lag bye ba'i rgya mtshor 'jug pa'i gru/_/mkhas pa'i ngag sgron gdeng can bsti ba'i gnas/_/glegs bshad chu klung 'bum gyi yongs gang ba/_blo ldan ngang mo rtse ba'i do ra che/_/dzad med rba rlab 'phyur ba'i par 'di ko ta_/lugs zung mkhyen pa'i lus stobs rmad byung sdes/_/dge bcu'i rgyal bstan 'degs la mi dal zhing /_/bgrangs yas bsod nams mtsho ba drug ldan pa'i/_/phun tshogs phan bde'i dra bas mdzas des bskrun/_de lta'i legs byas me shel khang bzang can/_/'khor gsum yang dag gzi 'od 'bum 'phro bas/_/mtha' med 'khor ba'i mun pa drung 'byin nas/_/rnam mkhyen rdzogs byang lam du bsgrod phyir bsngo//sar+wa dzayan+tu//_/_lha skyab kyis gso pa'o//. Circles underneath the text highlight the syllables sde dge, bsod rnams, and phun tshogs, that is, the name of the sDe dge ruler. The printer's colophon for the Dag yig li shii gur khang (Rin chen bkra shis, n.d., 16a.4-6) reads: om dza ya dza yan+tu/_gsung rab yan lag bcu gnyis chu gter che/_/gsar rnying brda tshig gting zab spog dka' ba/_/rnam dpyod khyor chur gsol byed li gur 'di/_/ thos bsam bdud rtsir bsgyur phyir mkha' la bskrun/_/brda tshig skom gyis gdungs ba'i phyin pa/_tshig don yan lag brgyad ldan da 'thungs shig_/grangs med gcig car bskrun pa'i chos sbyin 'di/_/sde dge lhun grub steng gi chos grwa ru/_/byang phyogs nor 'dzin chos bzhin skyong ba po/_/rdo rje 'dzin pa bsod nams phun tshogs kyis/_/par du bsgrubs pa'i legs byas gang thob pa/_/sangs rgyas bstan pa rgyas pa'i mchod par 'bul/_/dpe 'di phyi mo gnyis dang bstun nas bris shing dpang po po ta la'i par yig yid brten dang mi 'gal bar rgyas pa'i yan lag 'ga' zhig zhabs rtog gi tshul du bkod cing slan chad kyang zhus dag sogs 'dug na mdzad par zhu zhu/_yige pa ni bkra lus bgyis so/_sar+ba mang+galam//_b+ha wan+tu/.

19 In Tibetan: $r$ tsa 'grel 'di nyid 'dri klog mtha' dag la med du mi rung ba lta bu'i nges pa rnyed nas... The full printer's colophon (Chos skyong bzang po 1704, 25a.1-3) to this edition reads: ces pa bsil ldan ljong gi bstan pa'i srol 'byed chen po thon mi sam $+b+$ ho ta'i mdzad ba'i sum rtags rtsa 'grel 'di nyid 'dri klog mtha' dag la med du mi rung ba lta bu'i nges pa rnyed 
The training of scribes reached its apex in sDe dge during the large bKa' 'gyur and bsTan 'gyur projects, when grammatical texts were used to train dozens of people to work in the scribal workshops which prepared the texts that were to be carved onto blocks. Zhu chen mentions explicitly that knowledge of Thon mi Sam+b+ho Ta's works were necessary for the scholars working on the bsTan 'gyur project. In the same section describing the qualifications of his project workers, he also cites from dPal khang Lo tsā ba's Lamp of Speech (Tshul khrims rin chen 1985, 551.10-22). The editors of both the sDe dge bKa' 'gyur and bsTan 'gyur remark that the publications of the sDe dge court increased knowledge of writing in the region (Chos kyi 'byung gnas 2008, 416.11-20; Tshul khrims rin chen 1985, 554.2-556.4; and Schaeffer 2009, 104).

Bla brang, Textbooks, and the Institutionalizing of Printing

Let us now turn from kingdoms to monasteries and look briefly at the development of printing at Bla brang bKra shis 'khyil in A mdo in order to suggest some of the possible ways that a rapidly growing monastery might have used printing. Woodblock printing began at Bla brang in the mid-eighteenth century under the direction of the Second 'Jam dbyangs bzhad pa, dKon mchog 'jigs med dbang po (1728-1791). In the biography of dKon mchog 'jigs med dbang po we find several passages relating to the establishment of printing at Bla brang. The earliest reference is recorded when dKon mchog 'jigs med dbang po was just twenty-two years old, around the year 1749. At that time, he brought a block carver by the name of Blo bzang dar rgyas from g.Yer gshong to carve sādhana texts related to the previous 'Jam dbyangs bzhad pa's tutelary deity (dKon mchog bstan pa'i sgron me 2000, 37b.2-3). This episode seems to have been a limited affair which did not establish regular publishing activities at Bla brang, since later in the biography dKon mchog bstan pa'i sgron me states that before the iron snake (lcags sbrul) year of 1761 there was not a tradition of printing at Bla brang (69a.2-69b.3).

Then, in 1761, two years after dKon mchog 'jigs med dbang po's return from studying in central Tibet, he established woodblock printing as an integral part of Bla brang's activities. In that year,

nas sde dge lhun grub steng du sde dge gdan sa pa sangs rgyas bstan pas rab byung bcu gnyis pa'i nyi sgrol byed pa shing sprel lo'i sa ga can gyi zla ba'i dkar tshes la chos sbyin mi zad pa'i rgyun spel ba'i dge bas lung rtogs dam pa'i chos kyi tshig don 'khrul med dar zhing rgyas pa'i rtsa lag tu gyur cig/. 
Because all of the textual traditions had become rare, [dKon mchog 'jigs med dbang po] instructed Dar han chos rje [to act as] patron and Rab 'byams pa kun dga' bstan 'dzin [to act as] manager. Several monks were made to study block carving and afterward printing blocks for both the Mind and Signs (Blo rTags gnyis) were the first to be carved. Since then, the carving has been continuous and now has become a source of Dharma [in itself]. (dKon mchog bstan pa'i sgron me 2000, 69b.1-3) ${ }^{20}$

The Mind and Signs mentioned here by dKon mchog bstan pa'i sgron me refers to the textbooks on the topics of mental states (blo rig/rigs) and reasoning (rtags rigs) written by the founder of Bla brang monastery 'Jam dbyangs bzhad pa'i rdo rje Ngag dbang brtson 'grus (1648-1722). ${ }^{21}$ Here again, we see a desire to put into print the works of a significant lineage master, in this case the founder of the monastery and the immediate predecessor of dKon mchog 'jigs med dbang po in the line of 'Jam dbyangs bzhad pa incarnations. Indeed, these initial publications were followed by other works of 'Jam dbyangs bzhad pa'i rdo rje until his entire collected works had been carved by 1791 at the latest (Schaeffer 1999, 160). However, the selection of the Mind and Signs as the first works to be published after the formal establishment of printing at Bla brang could also be significant in other ways. These two works are the textbooks used at the beginning of monastic education in many dGe lugs pa monasteries. ${ }^{22}$ Prioritizing their publication might indicate an emphasis toward using printing

20 In Tibetan: sngar dgon 'dir par rkos rgyun chags kyi srol ma byung bas dpe rgyun thams cad dkon par yod pa'i stabs mnga' ris dar han chos rjer sbyin bdag dang /_rab 'byams pa kun dga' bstan 'dzin la gnyer gyi bka' phebs te/_grwa pa kha shas la par brko tshul slob tu bcug nas/_blo rtags gnyis kyi par thog mar brkos shing /_de nas bzung rgyun mi'chad du brkos pa da lta chos kyi 'byung gnas lta bur gyur te....

21 These two works are the rTags rigs kyi rnam bzhag nyung gsal legs bshad gser gyi phreng mdzes and Blo rig gi rnam bzhag nyung gsal legs bshad gser gyi phreng mdzes which are found in the Bla brang edition of 'Jam dbyangs bzhad pa'i rdo rje's collected works (see 'Jam dbyangs bzhad pa'i rdo rje, n.d., 14: 174-301 (rTags rigs) and 14: 303-374 (Blo rig)).

'Jam dbyangs bzhad pa'i rdo rje's textbooks were used at sGo mang college of 'Bras spungs and at Bla brang monastery, as well as at their affiliates. There were two other main sets of textbooks used in dGe lugs pa monastic colleges. The gradual standardization of curricula and the wider use of printing in the eighteenth century likely helped cement these texts in the curriculum as well as making them easier to disseminate among the increasing population of monks at large monastic centres. On the three main sets of textbooks, or manuals, and their standardization, see Dreyfus (2003, 124-25 and 143). Dreyfus also notes (148) that the textbooks of Bla brang monastery eventually came to be used even in some non-dGe lugs pa monasteries in A mdo, in particular rNying ma pa and Jo nang pa institutions. 
to supply study materials to monks of the monastery. This use of printing is attested at other major publishing centres in the eighteenth century. Pho lha gnas, the ruler of central Tibet from 1729 to his death in 1747, had published textbooks used at the three major dGe lugs pa monasteries in dBus. According to his biography by Tshe ring dbang rgyal, Pho lha gnas printed textbooks because "novice monks spent too much effort copying books and it was difficult for monks of little means to acquire copies" (translated and quoted in Schaeffer 2009, 116).

The printing of curricular materials which were distributed to monks at Bla brang is further suggested in an episode found within the history of Buddhism in A mdo known as the Ocean Annals (Deb ther rgya mtsho) by dKon mchog bstan pa rab rgyas (1801-1866). This episode occurred in the wood pig (sa phag) year, 1779, when Bla brang had just finished construction of its new assembly hall ('du khang). gTsang sprul sku bsTan pa rgya mtsho (1737-1780) was invited to Bla brang for the consecration of the new building. "At that time," the Ocean Annals tells us, "he acquired many print copies of bKra shis 'khyil's Collected Topics (bsDus grwa) and distributed them to the community of monks" (dKon mchog bstan pa rab rgyas 1975-77, 1:593.5-6). ${ }^{23}$ The Collected Topics mentioned here most likely refers to Opening the Golden Door to the Path of Reasoning: A Presentation of the Great Collected [Topics] (bsDus chen gyi rnam bzhag rigs lam gser gyi sgo 'byed) written by the First 'Jam dbyangs bzhad pa as a guide to the study of logic. ${ }^{24}$

Not only was Bla brang printing key texts for monastic studies, but printing itself became a skill which monks studied at Bla brang. By 1790, Bla brang's traditions of calligraphy and block carving were being disseminated to many of the forty or so branch monasteries under Bla brang at the time, helping to spread this technical knowledge to other locations in A mdo and Mongolia (dKon mchog bstan pa'i sgron me 2000, 240a.1-6; dKon mchog bstan pa rab rgyas $1975-77,2: 38.5)$. The regularization of printing within monastic training and more widespread knowledge of the craft may have had the unintended result of devaluing the skills associated with printing. In early central and western Tibetan prints, such as those from Mang yul Gung thang, one often sees carver's signatures. Franz-Karl Ehrhard (2000a, 69) has suggested that these signatures are a sign of the high esteem paid to the carvers. However,

23 In Tibetan: sa phag la 'du khang gzims khang bcas gsar bskrun grub pa'i rab gnas kyang rje de nyid la zhus/ de dus khong gis bkra shis 'khyil gyi bsdus grwa tshar mang po dpar nas bsnams pa grwa mang la bkram/.

24 This text is found in the Bla brang edition of 'Jam dbyangs bzhad pa'i rdo rje's collected works (see 'Jam dbyangs bzhad pa'i rdo rje, n.d., 14: 377-488). 
by the eighteenth century these types of signatures became rare in Tibetan xylographs. Instead, we read in the Ocean Annals that by the time of the twenty-fifth abbot of Bla brang monastery, dKon mchog seng ge (1768-1833), the ones who were made to study printing and calligraphy at Bla brang were monks of inferior intellect (dKon mchog bstan pa rab rgyas 1975-77, 2: 127.3). ${ }^{25}$

While the work of printing may not have carried great esteem at Bla brang, dKon mchog 'jigs med dbang po nevertheless certainly valued the technology of printing and had a genuine interest in making books available for reading and studying. We see this in his establishment of a library at Bla brang around the year 1775 when he was forty-eight years old. His biography tells us that:

Before this, although there was not a library (dpe $\mathrm{mdzod}$ ) tradition, he established a tradition for the purpose of benefiting those students of limited means, and quickly over one thousand books arrived and became a great benefit for continuous teaching. (dKon mchog bstan pa'i sgron me 2000, 130a.6-130b.1 $)^{26}$

Again we get the sense that there was a concern at Bla brang for making books available to students for study, and particularly those monks who could not obtain books otherwise.

At Bla brang, as at many printing houses large and small, the initial printing project was related to a recent master in the monastery's tradition, the collected works of 'Jam dbyangs bzhad pa'i rdo rje. However, the selection of certain works to prioritize as printed publications along with the overall interest of dKon mchog 'jigs med dbang po and others to make books more widely available suggests that the leaders of this rapidly growing monastery which housed several colleges looked to printing as a means of supplying study materials to students.

The increase in Tibetan woodblock publishing in the eighteenth century was truly a watershed in Tibetan printing. It might deservedly be called a Tibetan printing revolution; though our use of 'revolution' here is perhaps less in the

\footnotetext{
25 The pertinent statement reading: blo dman rnams la dpar dang yi ge slob bcug/.

26 In Tibetan: de sngon dpe mdzod kyi srol med kyang /_don gnyer can cha rkyen srab pa rnams la phan pa'i phyir de'i srol btsugs pas ma 'gyangs par po ti stong phrag brgal ba byung ste bstan rgyun la shin tu phan por song /.
} 
sense of revolutionary upheaval or change and more in the sense of a revolving wheel - a Dharma wheel. To turn the wheel of the Dharma (chos kyi 'khor lo bskor $b a$ ) is to teach or spread the Buddhist religion, and this purpose is mentioned in many Tibetan printing colophons. In that case, we could speak of eighteenth-century publishing, and other key eras in Tibetan printing, as 'printed revolutions of the Dharma wheel.'

In this paper I have given some preliminary evidence for the growth of Tibetan publishing during two particular periods, the fifteenth-sixteenth centuries and the eighteenth-nineteenth centuries. As shown by the publication histories of a selection of important Tibetan works, the bulk of xylograph editions fall into these two eras. Many of the larger projects that were undertaken in the earlier period were again taken up in the eighteenth century. Some of these publications were mainly continued in the latter century by printing houses affiliated with the school in which a particular work or collection was important. However, some works were able to transcend such sectarian identification and in the eighteenth century were widely published across geographic and sectarian boundaries.

Publishing was an expensive undertaking, and therefore was largely the prerogative of wealthy patrons, particularly political elites. In many cases, we see woodblock publishing following sources of patronage. In the fifteenth century, we see the importance of members of the ruling Phag mo gru pa government as patrons of early substantial printing projects in central Tibet. In western Tibet, the role of the court of Mang yul Gung thang was crucial to the efforts of early Bo dong pa and bKa' 'gyud pa publishers, including gTsang smyon $\mathrm{He}$ ru ka.

In the eighteenth century, printing patrons became increasingly common further east. We saw this in the Sa skya Ngor sect and the movement of prominent members of that school east to the sDe dge kingdom in Khams at a time when political and economic support in central Tibet was shifting decisively to the dGe lugs pa school. In sDe dge the abbots of Ngor found a rising political power willing to support major publishing projects. Later in the eighteenth century, sDe dge would increasingly support rNying ma pa publishing projects as well. rNying ma pa figures were also looking for greener pastures, having come under direct assult in central Tibet with the Dzungar invasion of 17171720 (Ronis 2009, 93).

Even members of the dGe lugs pa school were looking beyond central Tibet for patronage. This was probably due in part to the continuing political turmoil in central Tibet throughout the eighteenth century, of which the Dzungar invasion was just one of several unfortunate episodes, and in part to the rise of willing patrons in A mdo and China, including the Qing court, the Co ne kingdom, 
as well as Bla brang and sKum 'bum monasteries. In the eighteenth century Co ne became a major woodblock publisher, supported by the royal court of Co ne. In addition to the well-known bKa' 'gyur and bsTan 'gyur carved there, Co ne also produced woodblock editions of the complete collected works of Tsong kha pa and selected works by his primary disciples (dKon mchog 'jigs med dbang po 1986, 423.21-424.5). The first major publishing project at Bla brang was the collected works of its founder, the First 'Jam dbyangs bzhad pa. Even before that project was finished, dKon mchog 'jigs med dbang po intiated an effort to produce the works of mKhas grub rje dGe legs dpal bzang (dKon mchog bstan pa'i sgron me 2000, 86a.4-5).

Printing seems to have functioned, along side the building and maintainance of religious instutitions and monuments, as a powerful way for a ruler to perform the role of protector and benefactor of religion and the populace, that is, the ideal role of a Buddhist ruler. The fifteenth century and eighteenth century in particular were times when political leaders put significant resources toward woodblock publishing. Why these two periods in particular? The answer to that question is certainly complicated and involves many factors. I would, however, like to put forth a few possible reasons. The mid-fourteenth century saw the collapse of the Mongol supported Sa skya regime in Tibet. That regime had been headed, at least nominally, by the religious leaders of the Sa skya pa school. As the Phag mo gru pa gained power, the need to position themselves as strong Buddhist rulers may have been particularly acute given that the preceding regime had been headed by Buddhist lamas, whose religious credentials were more obvious. The Phag mo gru rulers probably felt the need to establish their legitimacy through patronage which included support for woodblock publishing. In the eighteenth century, there were likewise several emerging powers that were seeking to establish their credentials through patronage. Most of these supported both sectarian printing projects as well as the publication of classics.

Classics may have been particularly useful in regard to establishing one's authority and legitimacy, which could account for these works' popularity. This is especially true in the case of the Collected Pronouncements of the Mani, a treasure text (gter ma) whose composition is attributed to the Tibetan emperor Srong btsan sgam po. It is the primary text that establishes Avalokiteśvara as the special protector of Tibet while at the same time designating Srong btsan sgam po as a manifestation of this bodhisattva. It is thus a powerful statement on the sacred nature of Tibetan kingship. It is not surprising, then, that we find political figures again and again sponsoring its publication.

The governments of Bhutan and the dGa' ldan pho brang both promoted an image of their leaders as emanations of the bodhisattva Avalokiteśvara 
and made use of both ritual performance and the composition and printing of texts to reinforce this image (Ardussi 2004, 11). However, neither of these polities was particularly interested in printing the bKa' 'gyur or bsTan 'gyur. On the other hand, several lay rulers of the eighteenth century were extremely active in bKa' 'gyur and bsTan 'gyur publishing. It is worth considering whether the difference between reincarnate and lay ruler had something to do with the discrepancy in bKa' 'gyur and bsTan 'gyur printing activities. I think it is entirely possible that the reincarnate status of the Zhabs drung in Bhutan and the Dalai Lama in Lhasa provided them with an obvious religious legitimacy (like the Sa skya pa lamas during the Mongol era) that did not demand the publication of a bKa' 'gyur or bsTan 'gyur to reinforce. With the emergence of these new reincarnate political leaders, as well as the rising clout of reincarnate leaders of powerful monastic institutions like the 'Jam dbyangs bzhad pas of Bla brang, lay rulers probably more than ever felt the need to assert their religious credentials and reinforce their claims to be emanations of bodhisattvas. They were also competing with each other for the loyalty of subjects in a time of territorial expansion on all sides. In such a climate, the circumstances were right for the extensive patronage of religious endeavors including the publication of texts.

While prestige, authority, and legitimacy were all likely important motivations for patrons of printing, many eighteenth-century publications also had more tangible purposes. The motivation behind at least some eighteenthcentury publishing projects probably stemmed from a desire to train scribes and able administrators in expanding kingdoms and large monasteries. For the monasteries, there was likely also a need to provide texts used in the increasingly standardized monastic curricula of large religious institutions which housed several colleges and thousands of monks. Standard monastic curricula, as well as standard ritual calendars and liturgies, may have created a desire for standard texts to use for study and ritual performance. In these and other ways, the expanding polities and monasteries of the eighteenth century likely would have been interested in processes to enable effective administration and standards that could be used, and reproduced, across large bureaucracies and institutional structures. The demands of growing bureaucracy and increasing standardization would have been well met by the establishment of printing houses.

There were a number of interests and agendas that came together in the development of the large eighteenth-century printing houses. There were religious figures who sought to memorialize or promote their teachers and lineage. There were monastic leaders who saw in xylography a way to publish materials needed in a large monastic college setting, there were political leaders who saw the sponsorship of religious publishing as a way to reinforce their image as 
a Buddhist ruler while also using printed texts to train skilled administrators and promote religious and ritual activities that would bring them and their domains good fortune and protection. All of these interests came together in the printing house and the various books that issued from these publishing centers can be seen as fulfilling one or more of these desires. The different types of literature and uses of printed texts, while in some respects serving quite different purposes, were nevertheless all aspects of institutional authority in eighteenth-century Tibet. Although used in different ways, woodblock publications positioned eighteenth-century figures, religious and political, as legitimate leaders who provided opportunities for learning, merit making, and turning the wheel of the (printed) Dharma.

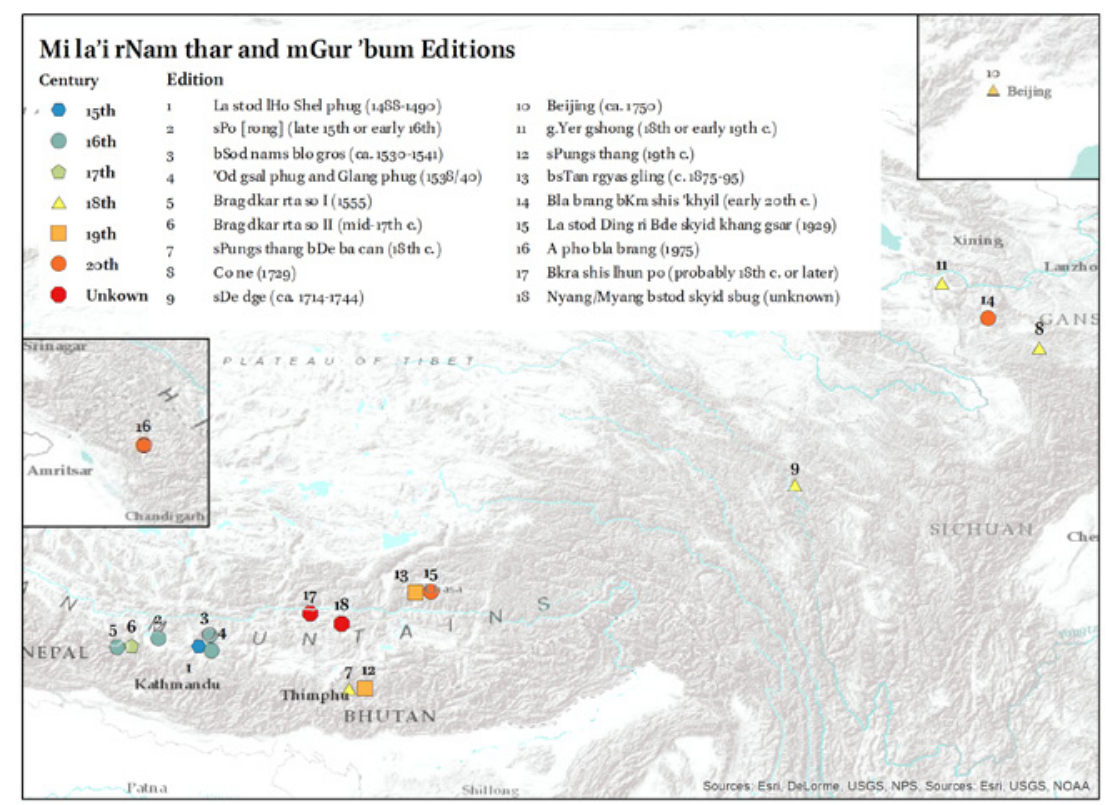

MAP 18.1 Xylograph editions of the Mi la ras pa'i rNam thar Mi la'i rnam thar and mGur 'bum. ${ }^{27}$

27 See Sernesi $(2011,180,188,191-92,202-206)$ on the dates and circumstances of production for the La stod lHo Shel phug, bSod nams blo gros, 'Od gsal phug/Glang phug, and Brag dkar rta so I and II. Several scholars have associated the sPo edition with a region of Khams by that name, but Sernesi (190-191) provides convincing evidence that this edition actually should be associated with sPo [rong] in western Tibet and is likely a reprint of a relatively early edition from that region. See Smith (2001, 70-73) on the dating of the sPungs thang bDe ba can, sDe dge, Beijing, sPungs thang, bsTan rgyas gling, and La stod Ding ri bDe skyid khang gsar editions. The dating of the Co ne print is clear from the colophon of the mGur 'bum, where it is stated that this edition was prepared in conjunction 


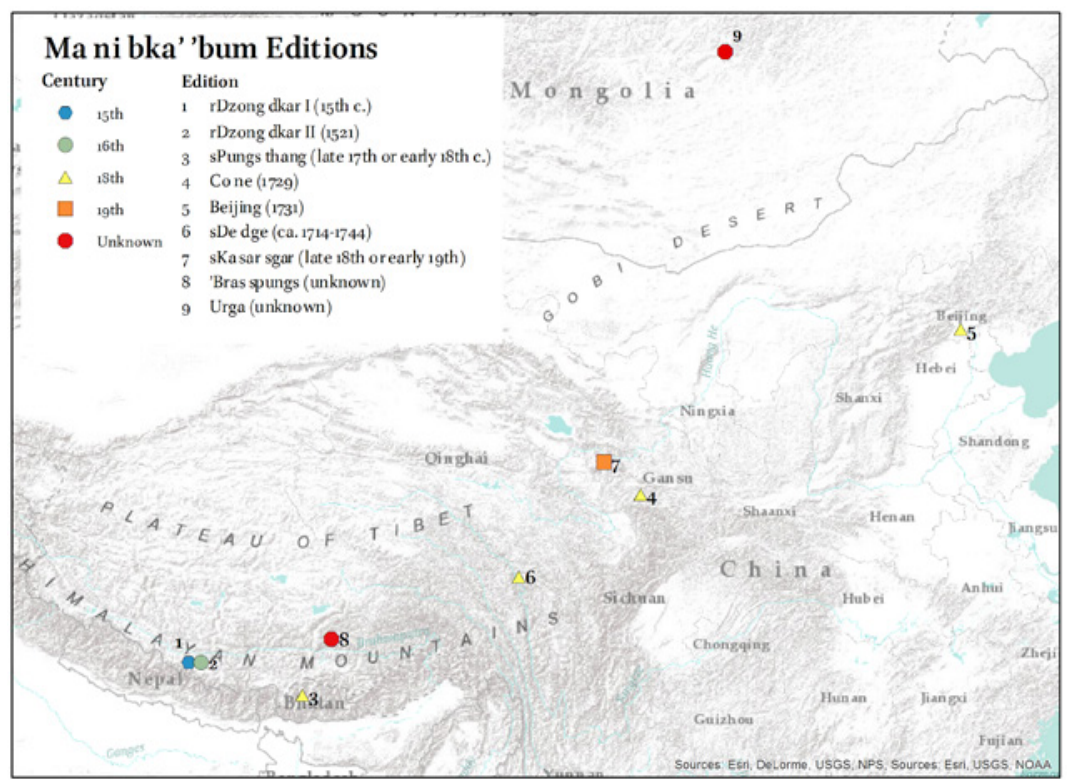

MAP 18.2 Xylograph editions of the Ma ni bka' 'bum. ${ }^{28}$

with the founding of the tantra college at the Co ne dgon chen. The colophon is reproduced by Eimer and Tsering $(1990,74-76)$. According to dKon mchog bstan pa rab rgyas (1975-77, 3: 264.4), the tantra college at Co ne was founded in a earth bird (sa bya) year of the twelfth rab byung, or 1729. The g.Yer gshong edition is mentioned by dKon mchog bstan pa rab rgyas (1975-77, 1: 774.6) and by Brag dkar rta so sPrul sku Chos kyi dbang phyug (1775-1837) in his history of the abbatial lineage of Brag dkar rta so titled Brag dkar rta so gdan rabs (for a translation of the relevant passage, see Sernesi (2011, 182-183)). As that work was written in 1816 and g.Yer gshong bSam gtan chos 'phel gling was founded in 1696 (dKon mchog bstan pa rab rgyas 1975-77, 1: 770.1), this edition most likely falls in the eighteenth century. The Bla brang bKra shis 'khyil edition of the rNam thar, a print of which is held at the Library of Congress in Washington, DC, contains a colophon written by the fourth 'Jam dbyangs bzhad pa, sKal bzang thub bstan dbang phyug (1856-1916), thus placing this edition in the late nineteenth or early twentieth century. According to Eimer and Tsering $(1990,83-84)$ the A pho bla brang edition was prepared in Europe, while the colophon to the edition states that the blocks are kept at Ci ta ri'i dgon in Manali, [India] (84). The dates of the Bkra shis lhun po and Nyang/Myang bstod skyid sbug editions are not known. As Eimer and Tsering note (1990, 66-68), these two editions are related, one likely being based on the other, though which was first is unknown. Bkra shis lhun po's printing house expanded significantly in the early eighteenth century under Pan chen Blo bzang ye shes (1663-1737) (Blo bzang 'phrin las 2004, 140). It would not be surprising to find that this edition dates from that era.

28 See Ehrhard (2000a, 14-15) on the two editions produced at rDzong dkar. No copies of the earlier edition are known to exist. Ehrhard's article on the dMar khrid Tshems bu lugs and the Mani bka' 'bum gives more details of the production of the $15^{21}$ edition 


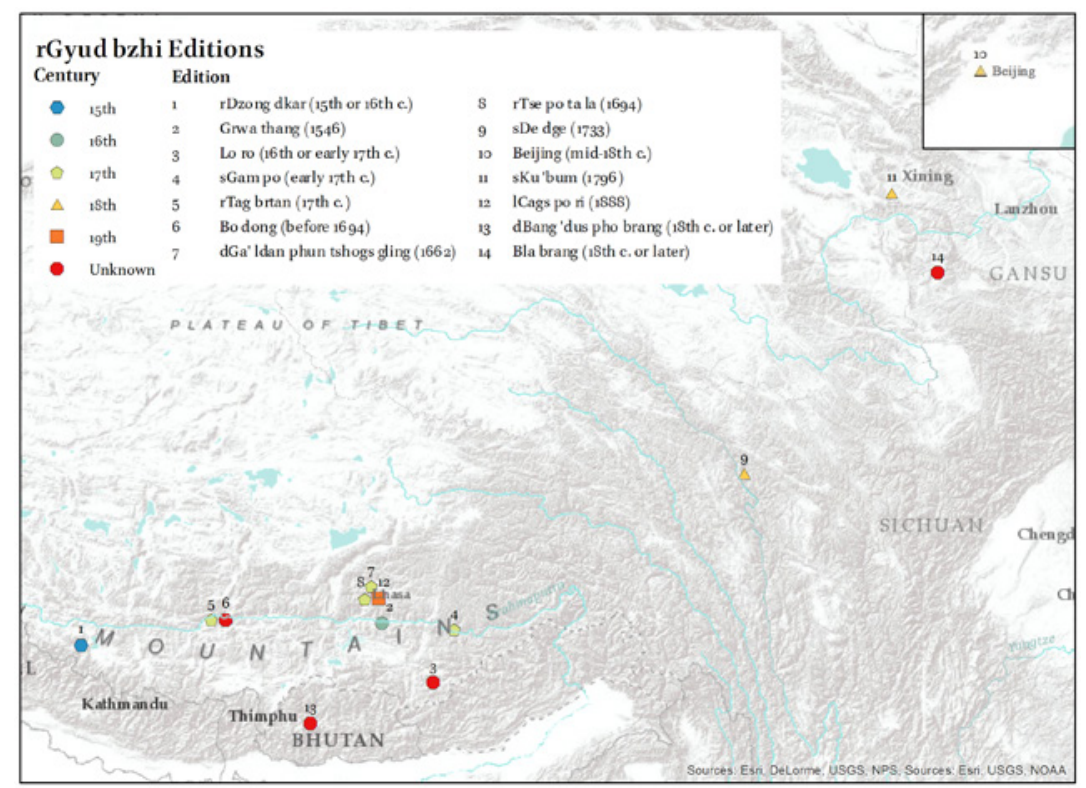

MAP 18.3 Xylograph editions of the rGyud bzhi. ${ }^{29}$

(Ehrhard 200ob, 199-215). Prints of the 1521 edition are held in the National Archives of Nepal and the University of Wisconsin Library's Department of Special Collections. A reprint of the sPungs thang edition has been published in India (Ma ni bka' 'bum 1975). The sPungs thang edition can be tentatively dated to the late seventeenth or early eighteenth century based on Sernesi's $(2011,202)$ identification of mNga' ris sgrub chen Ngag dbang chos 'phel, "who requested the carving of the Punakha edition of the Mani bKa' bum," as likely being the same as sGrub chen Ngag dbang chos 'phel who was a "main donor" of the print of Mi la ras pa'i rNam thar and mGur 'bum produced in the late seventeenth century and stored at Brag dkar rta so. While I know of no existing copies of the Co ne edition of the Ma ni bka' 'bum, the colophon to the Co ne edition of the Mi la ras pa'i mgur 'bum states that a xylograph edition of the Ma ni bka' 'bum was produced simultaneously with that publication in 1729 (Eimer and Tsering 1990, 76). The date for the Beijing edition is given in the colophon (reproduced in Taube 1966, 1086, entry 2926), as the eighth year of the Yongzheng emperor, 1730/31. A print of this edition is held by the Library of Congress in Washington, DC. The general time frame of the sDe dge edition is reported by Zhu chen Tshul khrims rin chen in his catalogue of the sDe dge edition of the bsTan 'gyur (composed in 1744), where he places the production of the edition during the reigns of the sDe dge kings bsTan pa tshe ring (r. 1714-1738) and Phun tshogs bstan pa (r. 1738-1751) (Tshul khrims rin chen 1985, 450.12-13). Thus, this edition would have been made at some time between bsTan pa tshe ring's taking the throne of sDe dge in 1714 and the composition of the bsTan 'gyur catalogue in 1744. твRс holds scans of this edition: WiKG10871 (http://www.tbrc.org/\#!rid=W1KG10871). The sKa sar sgar edition is reported by dKon mchog bstan pa rab rgyas (1975-77, 1: 778.6). This edition would have been made 
between the founding of sKa sar sgar in the late eighteenth century and the completion of the Deb ther rgya mstho in 1865 . The dates of the 'Bras spungs and Urga editions are not known. The 'Bras spungs edition is listed in a catalogue of central Tibetan printing houses. It is found under blocks held by the Go bo khams tshan of Blo gsal gling college (Gangs can gyi ljongs 1970, 189). The Urga edition is listed and its colophon reproduced by Taube (1966, 1081-1085, entry 2925A). The print of the edition catalogued by Taube is held in the Staatsbibliothek in Berlin.

29 There are some discrepancies in the dating of the rDzong dkar edition. The introduction to the comparative edition published recently in Beijing identifies the sponsor as mNga' ris rgyal po Khri lde bSod nams dbang phyug (bsTan 'dzin don grub 2008, 3), whose dates are 1577-1621. This accords with the brief mention in the colophon of a "Khri lde bSod nams." However, Franz-Karl Ehrhard (2000a, 14-15) has argued for a much earlier rDzong dkar edition, based on textual sources which mention Chos rje Kun dga' rgyal mtshan (d. 1466) as an editor. Ehrhard therefore concludes that the sponsor was likely Khri rNam rgyal lde (1422-1502). There is of course the possibility that two editions, an earlier and later, were produced in Mang yul Gung thang. See Ehrhard (2000a, 15) for the dating of the Grwa thang edition. The date of the Lo ro edition is not explicitly mentioned in the colophon (reproduced in bsTan 'dzin don grub 2008, 691-699), but based on some of the figures mentioned we can roughly date it to the sixteenth or early seventeenth century. The editor of this edition, Tshe dbang bsam grub, is identified as a disciple of a certain Zla ba'i bzang po. A medical figure of this name is mentioned by Martin (1997, 83, entry 154). Martin places him tentatively in the sixteenth century. The colophon to the Lo ro edition further indicates that the edition was made during or shortly after the life of 'Jam dbyangs bstan 'dzin grags pa, later mentioned as the first sByor ra sprul sku. He seems to have died in the early seventeenth century, based on a relative chronology that can be drawn from the ages at death given for the first five sByor ra sprul sku (the last of whom was born in 1770) which can be found under твкс: $\mathrm{P}_{7007}$ (http://www.tbrc.org/\#!rid=P7007). See bsTan 'dzin don grub $(2008,2-4)$ on the sGam po, rTag brtan, dGa' ldan phun tshogs gling, rTse po ta la, sDe dge, Beijing, sKu 'bum, lCags po ri, and Bla brang. The Bo dong edition must have been prepared before 1694 since it was consulted by Sangs rgyas rgya mtsho in the editing of his edition produced that year (Schaeffer 2009, 78). The date of the sKu 'bum edition, the earth male horse (sa pho rta, or 1796) year is found in the colophon (bsTan 'dzin don grub 2008, 705). The date for the lCags po ri edition is given in the preface to the Indian reprint ( $r G y u d$ bzhi 1978). The dates of the dBang 'dus pho brang Chos 'khor rab brtan and Bla brang editions are not known. The dBang 'dus pho brang Chos 'khor rab brtan edition probably, like most prints from Bhutan, dates from the eighteenth century or later. The same is true for the Bla brang edition - Bla brang's printing house only being established in the mid-eighteenth century. The colophons for the Grwa thang, sGam po, rTag brtan, Lo ro ("Lor"), rDzong dkar, dGa' ldan phun tshogs gling, rTse po ta la ("rTse zhol"), lCags po ri, Beijing ("Pe cin"), and sKu 'bum editions are transcribed by bsTan 'dzin don grub (2008, 689-705). The editors of the dPal ldan rgyud bzhi also mention a possible Mongolian (Sog yul) edition (bsTan 'dzin don grub 2008, 3-4). They further mention (3) that the rDzong dkar edition was based on an edition from Gong dkar byar yul but no further information concerning such an edition is given. 


\section{Bibliography}

\section{Tibetan Sources}

Blo bzang 'phrin las, Dung dkar. 2004. Bod kyi dkar chag rig pa. Vol. 2 of mKhas dbang Dung dkar Blo bzang 'phrin las kyigsung 'bum. Beijing: Mi rigs dpe skrun khang.

bsTan 'dzin don grub, ed. 2008. dPal ldan rgyud bzhi. Beijing: Krung go'i bod rig pa dpe skrun khang.

Chos kyi 'byung gnas, Si tu pan chen (1699-1774). 2008. rGyal ba'i bka' 'gyur rin po che'i bzhugs byang dkar chag [bDe bar gshegs pa'i bka' gangs can gyi brdas drangs pa'i phyi mo'i tshogs ji snyed pa par du bsgrubs pa'i tshul las nye bar brtsams pa'i gtam bzang po blo ldan mos pa'i kunda yongs su kha byed ba'i zla 'od gzhon nu'i 'khri shing]. Chengdu: Si khron dpe skrun tshogs pa, Si khron mi rigs dpe skrun khang.

Chos skyong bzang po (1441-1527). 1704. 'Gos lo tsā ba d+harma pā las mdzad pa'i bod kyi brda'i bye brag legs par bshad pa sum cu pa dang rtags kyi 'jug pa'i rtsa 'grel. sDe dge: sDe dge par khang.

dKon mchog bstan pa rab rgyas (1801-1866). 1975-77. Deb ther rgya mtsho [The Ocean Annals of Amdo: Yul mdo smad kyi ljongs su thub bstan rin po che ji ltar dar ba'i tshul gsal bar brjod pa deb ther rgya mtsho]. 3 volumes. Delhi: Sharada Rani. твRс: W6004. http://www.tbrc.org/?locale=en\#!rid=W6oo4.

dKon mchog bstan pa'i sgron me, Gung thang 3 (1762-1823). 2000. dKon mchog 'jigs med dbang po'i rnam thar [Dus gsum rgyal ba'i spyi gzugs rje btsun dkon mchog 'jigs med dbang po'i zhal snga nas kyi rnam par thar pa rgyal sras rgya mtsho'i 'jug ngogs]. In dKon mchog bstan pa'i sgron me'i gsung 'bum, vol. 4 (nga), 207-722 (259ff.). Lhasa: Zhol par khang gsar pa. TвRс: W22112. http://tbrc.org/link?RID=OooCHZo10208o|O ooCHZo102080ooCHZo102456W22112.

dKon mchog 'jigs med dbang po, 'Jam dbyangs bzhad pa 2 (1728-1791). 1986. Co ne'i bstan 'gyur dkar chag [bDe bar gshegs pa'i bka'i dgongs 'grel bstan bcos 'gyur ro cog par du sgrub pa'i tshul las nye bar brtsams pa'i gtam yang dag par brjod pa dkar chag nor bu'i phreng ba]. Lanzhou: Kan su'u mi rigs dpe skrun khang.

dKon mchog lhun grub, Ngor chen (1497-1557), and Ngor chen Sangs rgyas phun tshogs, (1649-1705). 1973. A History of Buddhism: Being the Text of Dam pa'i chos kyi byun tshul legs par bśad pa bstan pa rgya mtshor 'jug pa'i gru chen źes bya ba rtsom 'phro kha skon bcas. New Delhi: Ngawang Topgey. твRс: W30267. http://www.tbrc .org/\#!rid=W30267.

Gangs can gyi ljongs su bka' dang bstan bcos sogs kyi glegs bam spar gzhi ji ltar yod pa rnam nas dkar chag spar thor phyogs tsam du bkod pa phan bde'i pad tshal 'byed pa'i nyin byed. 1970. In Three Dkar Chag's, 169-243. New Delhi: Ngawang Gelek Demo.

Kun dga' rgyal mtshan, Sa skya pạ̣ịi ta (1182-1251). 1705. Sa skya legs bshad. sDe dge: sDe dge par khang. 
'Jam dbyangs bzhad pa'i rdo rje. n.d. 'Jam dbyangs bzhad pa'i rdo rje'i gsung 'bum. 14 volumes. Bla brang bKra shis 'khyil. твRC: W22186. http://www.tbrc.org/\#!rid= W22186.

Lessing Collection. University of Wisconsin-Madison Libraries, Department of Special Collections.

$\mathrm{Mu}$ po, ed. 2002. Lam 'bras bla ma brgyud pa'i rnam thar [gSung ngag rin po che lam 'bras bla ma brgyud pa'i rnam thar kun 'dus me long]. Beijing: Mi rigs dpe skrun khang.

Ngag dbang chos kyi rgya mtsho, dPal khang (15th/16th c.). n.d. (early 18th c.). Bod kyi brda'i bye brag gsal bar byed pa'i bstan bcos tshig le'u byas pa mkhas pa'i ngag gi sgron ma. sDe dge: sDe dge par khang.

rGyud bzhi: A Reproduction of a Set of Prints from the 1888 Lha-sa Lcags-po-ri Blocks. 1978. Leh: T. S. Tashigangpa, 1978. твRC: W30134. http://www.tbrc .org/?locale $=\mathrm{en} \#$ !rid $=\mathrm{W}_{30134}$.

Rin chen bkra shis, sMon grub lo tsā ba (b. 15th c.). n.d. (early 18th c.). Dag yig li shi'i gur khang [Bod kyi skad las gsar rnying gi brda'i khyad par ston pa legs par bshad pa li shi'i gur khang]. sDe dge: sDe dge par khang. тв RC: W27219. http://www.tbrc .org/?locale=en\#!rid=W27219.

The Tibetan Tripitaka: Peking Edition. 1961. Edited by Daisetz T. Suzuki. Tokyo and Kyoto: Tibetan Tripitaka Research Institute.

Tshe dbang rdo rje rig 'dzin. 1994. sDe dge rgyal rabs [dPal sa skyong sde dge chos kyi rgyal po rim byon gyi rnam thar dge legs nor bu'i phreng ba 'dod dgu rab 'phel]. Bir, Distt. Kangra, H. P.: D. Tsondu Senghe Yorey Tsang. TBRC: W23737. http://www.tbrc .org/?locale $=$ en\#!rid=W23737.

Tshul khrims rin chen, Zhu chen (1697-1774). 1985. bsTan 'gyur dkar chag [Kun mkhyen nyi ma'i gnyen gyi bka' lung gi dgongs don rnam par'grel ba'i bstan bcos gangs can pa'i skad du 'gyur ro 'tshal gyi chos sbyin rgyun mi 'chad pa'i ngo mtshar 'phrul gyi phyi mo rdzogs ldan bskal pa'i bsod nams kyi sprin phun rgyas par dkrigs pa'i tshul las brtsams pa'i gtam ngo mtshar chu gter 'phel ba'i zla ba gsar pa]. Lhasa: Bod ljongs mi dmangs dpe skrun khang.

\section{Other Sources}

Ardussi, John. 2004. "Formation of the State of Bhutan ('Brug gzhung) in the 17th Century and its Tibetan Antecedents." Journal of Bhutan Studies 11, no. 2: 10-32.

Dreyfus, Georges B. J. 2003. The Sound of Two Hands Clapping: The Education of a Tibetan Buddhist Monk. Berkeley: University of California Press.

Ehrhard, Franz-Karl. 2000a. Early Buddhist Block Prints from Mang-yul Gung-thang. Lumbini: Lumbini International Research Institute. 
200ob. "The Transmission of the dMar khrid Tshems bu lugs and the Mani bka' 'bum." In Vividharatnakarandaka: Festgabe für Adelheid Mette, 199-215. SwisttalOdendorf: Indica et Tibetica.

Eimer, Helmut and Pema Tsering. 1990. "Blockprints and Manuscripts of Mi la ras pa's Mgur 'bum Accessible to Frank-Richard Hamm." In Frank-Richard Hamm Memorial Volume, edited by Helmut Eimer, 58-88. Bonn: Indica et Tibetica Verlag.

Fushimi, Hidetoshi. 1999. "Recent Finds from the Old Sa-skya Xylographic Edition." Weiner Zeitschrift für die Kunde Südasiens 43: 95-108.

Jackson, David P. 1983. "Notes on Two Early Printed Editions of Sa-skya-pa Works." The Tibet Journal 8, no. 2: 3-24.

1989. "More on the Old dGa'-ldan and Gong-dkar-ba Xylographic Editions." Studies in Central and East Asian Religions 2: 1-18. 1996. A History of Tibetan Painting. Wien: Verlag der Österreichischen Akademie der Wissenschaften.

Kolmas, Joseph. 1968. A Genealogy of the Kings of Derge. Prague: Oriental Institute of the Czechoslovak Academy of Sciences.

van der Kuijp, Leonard. 1993. "Two Mongol Xylographs (Hor Par Ma) of the Tibetan Text of Sa Skya Paṇita's Work on Buddhist Logic and Epistemology." Journal of the International Association of Buddhist Studies 16, no. 2: 279-298.

2004. The Kälacakra and the Patronage of Tibetan Buddhism by the Mongol Imperial Family. Central Eurasian Studies Lectures 4. Bloomington, IN: Department of Central Eurasian Studies, Indiana University.

Martin, Dan. 1997. Tibetan Histories: A Bibliography of Tibetan-Language Historical Works. London: Serindia Publications.

Ronis, Jann. 2009. "Celibacy, Revelations, and Reincarnated Lamas: Contestation and Synthesis in the Growth of Monasticism at Katok Monastery from the 17th through the 19th Centuries." PhD diss., University of Virginia.

Schaeffer, Kurtis R. 1999. "Printing the Words of the Master: Tibetan Editorial Practice in the Collected Works of 'Jam dbyangs bzhad pa'i rdo rje I (1648-1721)." Acta Orientalia 6o: $159-177$.

2009. The Culture of the Book in Tibet. New York: Columbia University Press.

Sernesi, Marta. 2011. "A Continuous Stream of Merit: The Early Reprints of gTsang smyon Heruka's Hagiographical Works." Zentralasiatische Studien 40: 179-237.

Smith, E. Gene. 2001. Among Tibetan Texts: History and Literature on the Tibetan Plateau. Boston: Wisdom.

2004. "Banned Books in the Tibetan Speaking Lands." In 21st Century Tibet Issue: Symposium on Contemporary Tibetan Studies, Collected Papers (Dang dai zang xue xue shu yan tao hui: lun wen ji), 364-81. Taipei, Taiwan: Mongolian and Tibetan Affairs Commission (Meng Zang wei yuan hui). 
Taube, Manfred. 1966. Tibetische Handschriften und Blockdrucke. Vol. 4. Verzeichnis der Orientalischen Handschriften in Deutschland, XI. Weisbaden: Franz Steiner Verlag. Zhaxia, ed. 2008. Zangwen «Dazangjing» gailun. Xining: Qinghai renmin chubanshe. Zwilling, Leonard. 1984. Tibetan Blockprints in the Department of Rare and Special Collections. Occasional Papers of the University of Wisconsin-Madison Libraries 5 . Madison: The University of Wisconsin-Madison Libraries. 